\title{
Speaking the Lacuna: The Archaeology of Plantation Slavery as Testimony
}

-Esther Wolfe, Ball State University

I $\mathrm{n}$ Remnants of Auschwitz: The Witness and the Archive, Georgio Agamben uses the framework of the Holocaust, specifically the Auschwitz death camp, to interrogate the very nature of testimony and the position of the witness. According to Agamben, witness testimony to the Holocaust from survivors of the camp occupies a particular hinge: "On the one hand, what happened in the camps appears to the survivors as the only true thing and, as such, absolutely unforgettable; on the other hand, this truth is to the same degree unimaginable, that is, irreducible to the real events that constitute it" (12). This hinge of the unimaginable and the incomprehensible,

\section{Abstract:}

This paper examines plantation archaeology as a form of material testimony and bearing witness to the historical trauma of slavery. Exploring intersections of literary and spatial analysis, and using a critical framework that combines Agamben, Weizman, and Felman, the author argues that the material testimony of plantation archaeology embodies a "lacuna" of witnessing, and may even replicate historical dynamics of violence.

\section{KEY WORDS:}

Slavery, archaeology, forensics, anthropology, trauma studies, Shoshana Felman, Giorgio Agamben, Eyal Weizman the unforgettable and the inarticulateable, is characteristic of "the aporia of Auschwitz," "a reality that necessarily exceeds its factual elements." However, this aporia is also indicative of a "lacuna" specifically imbedded in the nature of testimony itself. According to Agamben, "At a certain point, it became clear that testimony contained at its core an essential lacuna; in other words, the survivors bore witness to something it is impossible to bear witness to" (12). This zone of indistinction between the knowable and unknowable, of meaning that can never be externalized but exists only in retreat, makes up the "lacuna" of witnessing, the inherent impossibility of bearing witness that characterizes the act of witnessing itself.

Agamben's theory of the "lacuna" of witnessing, by dealing exclusively with the writing and speaking subject, appears to engage only literary and witness forms of testimony. However, the "lacuna" of testimony contains an inherent material, spatial, and forensic dimension imbedded at the site of its etymology. The term "lacuna" means "a missing portion in a manuscript," as well as both "an unfilled space or gap" and "a cavity or depression, especially in bone." While the "lacuna" of Agamben's definition is applied explicitly to witness testimony in his work, the etymology of the term implicitly includes other testimonial forms. By referencing "a missing portion in a manuscript," alongside "an unfilled space or gap" and "a cavity or depression, especially in bone," the 
etymology of "lacuna" alludes to an unexplored and fundamental relationship between witness and literary testimonies and the material testimony of objects and spaces. In this way, the etymology of "lacuna" also hints at the ways in which material, forensic, and archaeological forms of testimony may also embody the crisis and inherent impossibility of bearing witness.

In its contemporary context, forensic archaeology has become increasingly utilized as a method to structure political interventions on behalf of victims of atrocity, to investigate and expose violence, to commemorate its events, to recognize the presence of historical trauma in contemporary life, and to pursue a project of collective healing. According to Keenan and Weizman, the advent of forensic aesthetics fundamentally shifted the privileging of witness testimony to that of the material testimony of objects. As Weizman also points out, this critical shift in the aesthetics of public truth-construction is fundamentally rooted in the desire to resolve the instability of witness testimony (Keenan and Weizman, 23). In this way, by privileging material, forensic, and archaeological methods of representation over witness testimony, it could be argued that this shift engages a belief in the ability of these methods to resolve the "lacuna" of testimony by extracting and representing a pure externalization, an objective reality of the memory and experience of trauma.

This belief is reflected in the methods of the archaeology of slavery. According to archaeologist scholar Patricia Samford, "[T] he lives of slaves, in many respects, are shadowy and inaccessible. Because most of the enslaved were kept from learning to read and write, their thoughts and emotions come to us only indirectly" (2). In an apparent parallel to this perceived inadequacy, Samford argues that the past of enslaved Africans are "visible now only to archaeologists, who carefully record and excavate the soil stains and brick foundations and preserve the thousands of artifacts revealed by digging" (3). In this way, Samford's scholarship communicates a critical shift: a privileging of material, forensic, and archaeological testimony over witness testimony, rooted in the belief that these methods allow us to excavate and represent the memory and objective reality of slavery.

However, plantation archaeology embodies a fundamental site of paradox. According to Samford, "Just as historians make it possible for the words written by long-dead individuals to come to life, so too a skilled archaeologist can coax silent objects to speak" (3). Here, Samford's language reveals a site of rupture and collapse within the supposed objectivity of material, forensic, and archaeological testimony. For, if plantation archaeology is meant to resolve the inherent "lacuna" of slave witness and literary testimony by recovering an objective reality of slavery, what then does it mean to make objects "speak" if the act of speech and the position of the speaking subject is rendered unstable and impossible via testimony? Within plantation archaeology, what is the relationship between witness/literary testimony and the testimony of objects and space? And, in what ways does the material testimony of plantation archaeology embody the "lacuna" of literary and witness testimony?

This analysis enacts multiple analytic processes to examine plantation archaeology as a form of testimony and bearing witness to the atrocity of slavery. By applying literary analysis to material testimony of slavery and by exploring representation of material testimonies in the literature of slavery, this paper aims to open up the relationship between literary and material testimonies of slavery. Using a critical framework that synthesizes Agamben's theory of the "lacuna" of testimony, Shoshanna Felman's concept of the "irreducibility” of literature, and Eyal Weizman's concept of critical forensic practice, I examine the relationship between the literary and material testimony of slavery, as well as the forensic methods and digital archives of plantation archaeology. Using this framework, I aim to address what I have come to view as critical gaps in dialogue and application within intersections of mainstream trauma studies, comparative slavery studies, and the field 
of critical forensic practice.

First, while Agamben's theory of the "lacuna" of witnessing and testimony has been historically important to the development of mainstream trauma studies, many have also noted the conspicuous absence of slavery from this framing. Similarly, while Felman has famously explored the relationship between literature and testimony, particularly the inherent "irreducibility" of literature and the inability of literary analysis to go "outside itself" in order to produce a pure externalization of meaning, the implications of this relationship to material forms of testimony, particularly the material testimony of slavery, remains obscured (Felman, Writing and Madness: Literature/Philosophy/Psychoanalysis). In addition, while Weizman and other theorists within the field of critical forensics have analyzed the archaeology of many sites of historical atrocity and the relationship of these methods to knowledge production and the management of cultural trauma (including Holocaust concentration camps, Bosnian death camps, genocides in South America, and the colonial archaeology of Israel in the Palestinian territories), as of yet this critical forensic framework has not been used to analyze the archaeology of the transatlantic slave trade in the U.S.

In an effort to address these identified gaps, this paper makes several arguments. In the first section, I present an analysis of a section from Toni Morrison's novel A Mercy. In this section of analysis, I identify the material and spatial dimensions of Morrison's literary testimony and bearing witness to the atrocity of slavery. Here, I argue that there is a fundamental relationship between literary and material testimonies of slavery and that the study of witness and literary testimony of slavery also inevitably illuminates these material forms. Analyzing the material testimony of Morrison's literary witnessing allows us to begin identifying the ways in which the material testimony of slavery is implicated in the "lacuna" of literary forms of bearing witness. In this way, the inseparable folding of the material and literary testimony of slavery in A Mercy allows us to identify the relationship between literary and material testimony within the archaeology of plantation slavery and frame an analysis of the particular "lacuna" of plantation archaeology.

In the proceeding sections, I apply Felman's literary theory to the methodology of plantation archaeology as a form of testimony and, specifically, to the archaeological methods of forensic osteological analysis and digital object archives. Here, I argue that the forensic methodology and digital archives of plantation archaeology, rather than resolve the "lacuna" of slave testimony by excavating and representing a purely externalized memory of slavery, instead are tainted always by their own processes of meaning-making. By analyzing the forensic methodology of osteological analysis, as well as the digital archives of the Digital Archive of Comparative Slavery, I will show that these methods, rather than recover the traumatic memory of slavery and enact an intervention against its violence, instead work to erase the historical trauma of slavery and rhetorically repeat the very structures of the violence of slavery itself. In this way, I argue that the "lacuna" of plantation archaeology ultimately further emphasizes that the traumatic memory and experience of slavery exists outside the possibility of excavation.

\section{Literature and Trauma: The Material Testimony of Florens's “Telling” in A MerCy}

The ending of $A$ Mercy, Toni Morrison's devastating novel exploring intersecting systems of slavery, violence, and trauma in colonial America, contains a pivotal scene. In the text, the character Florens, a young, enslaved black woman, is subjected to compounded structural and interpersonal violence and abuse. Born into slavery, rejected by her mother and sold to a new master (to "save" her from sexual abuse from her previous master, unbeknownst to Florens), and 
later violently rejected by the older, free black man who takes her as a lover, Florens ultimately returns to the farm she left, where her master has since died. Each night, in his room, on the walls of her master's house, Florens carves her "telling," her understanding of what has happened to her, her representation of her own trauma. "I am holding light in one hand and carving letters by the other. My arms ache but I have need to tell you this" (189). Here, Florens's "telling" "I am holding light in one hand and carving letters by the other"), as well as her expressed need to tell ("My arms ache but I have need to tell you this"), reveals her "telling" as a form of testimony, a method of bearing witness to the memory and violence of slavery. But what manner of testimony is Florens's telling? Probing this question reveals an inherent doubling of testimony, an inseparable folding between witness, literary, and material testimonial forms. Florens's “telling” is, fundamentally, a witness testimony: she wishes to speak her understanding of her traumatic experience, to externalize the internal truth of what has happened to her. However, the act of externalization that transforms Florens into a speaking subject in order to bear witness also orients her "telling" within the realm of literary testimony. "If you never read this, no one will. These careful words..." (188). In the act of externalization, by becoming "letters of talk," and "careful words," Florens's "telling" undergoes an inevitable process of translation, a passing from language into discourse that can now be "read" and interpreted as text. However, in this very act of externalization, in the passage of language into discourse, Florens's "telling” folds again into another realm of testimony via the method of telling itself. "There is no more room in this room. These careful words cover the floor ... Round and round, side to side, bottom to top, top to bottom all across the room" (189). In the act of carving the "careful words" into the wall, Florens's witness and literary testimony also becomes material testimony. Carved into the wall, her "telling" becomes image and object, space and architecture. In this way, Florens's "telling” also takes on a forensic and archaeological dimension which is left behind where she hopes her traumatic memory and meaning of the experience of slavery will be excavated and unearthed.

This doubling and slippage between witness, literary, and material forms of testimony in Morrison's work points to a fundamental relationship, a simultaneous blurring, between testimonial forms. Florens's "telling” reveals that witness, literary, and material testimony of slavery, rather than falling into separable hierarchy, continuously folds and refolds, passing into and out of one another, leaving behind and mingling with the residue of other forms. In this way, Morrison implicitly destabilizes hierarchies of witnessing that privilege material testimony. Forens's "telling" reveals that the material testimony of slavery always contains a trace of the literary, while literary testimony is revealed as material.

The slippage between witness, literary, and material testimony in Morrison's novel also reveals the ways in which the material testimony of Florens's "telling" embodies the "lacuna" of bearing witness. Florens's "telling" literalizes an inherent blurring of subject and object imbedded within testimony; in the act of carving her "telling" into the wall, Florens's enunciation as subject is literally objectified. Similarly, in the act of being carved into, the object of the wall becomes subjectified, as the "talking room" is literally made to "speak." However, Florens's "telling," in the attempt to purely externalize and capture meaning, is soon revealed as a further deferral and alienation of representation. As she carves her "telling," Florens realizes that the one she leaves it for will never understand it. "Sudden I am remembering. You won't read my telling. You read the world but not the letters of talk. You don't know how to" (188). Her telling is untranslatable and unrepresentable, and its meaning cannot be extracted, instead existing always in deferral and retreat. This inaccessibility, the unrepresentable nature of her testimony, the inherent impossibility of externalizing her experience, is doubled by the 
reader as audience. Although we are told of Florens's "telling," it is only described to us-we have no access to the "letters of talk" themselves. They are never revealed to us; as a result, we cannot read them, only about them. This perpetual deferral of meaning is further performed by the text itself, particularly in the lexical disjuncture of the speaking "I," as well as the text's use of metaphor and simile. In the text, Florens as speaking subject, articulated in "I," is often out of joint with grammatical structure. "Sudden I am remembering," "I am become wilderness ...” (188-189). Here, the lexical disjuncture of the "I" of testimony performs the impossibility of bearing witness. Florens's speaking subject, always out of joint, cannot externalize and articulate itself; thus, the meaning of her testimony is always displaced and alienated by the very act of externalization undertaken. The meaning of her testimony, its representation, cannot be purely extracted; rather, the act of testimony becomes another deferral of meaning.

This impossibility of testimony, its perpetual deferral of meaning, is also performed by the use of metaphor and simile within the text. "Perhaps these words need the air that is out in the world. Need to fly up then fall, fall like ash over acres of primrose and mallow" (188). Florens, speaking on her own testimony, describes it in terms of simile and metaphor. Here, via the function of metaphor, Florens's testimony, the meaning of her experience, is again inherently displaced by the very attempt to externalize it. In metaphor, what is described is framed not in terms of what it is, but specifically as what it is not. In this way, Florens's use of metaphor again performs the impossibility of testimony - rather than creating a pure externalization of experience, the act of "telling" creates a further deferral of meaning and representation. Similarly, with the use of simile, what is being described is framed as "like" something but is also fundamentally not that thing. In this way, Florens's “telling," her representation of experience, exists always in this in-between space of inarticulation. Through the use of simile and metaphor, Florens's testimony is defined always in terms of absences and gaps, its meaning perpetually deferred, impossible to truly externalize. Florens's "telling," in the act of being self-reflexively described, in the act of being read "about" by the audience, performs a testimony of testimony, the readers ultimately bearing witness to the act of bearing witness. Like the "letters of talk" circling her master's room, Florens's "telling," as witness, literary, and material testimony, exists always in excess of its framing.

Florens's "telling" reveals a fundamental slippage between witness, literary, and material testimony of slavery. As a result, Florens's material testimony also embodies an endless deferral of meaning and externalization, performing the impossibility of bearing witness. Morrison's framing allows us to identify similar slippage within the testimony of plantation archaeology, as well as the ways in which the material testimony of plantation archaeology, in the form of osteological analysis and digital object archives, also embodies a "lacuna" of bearing witness.

\section{Methodologies of Violence And Erasure: An Examination of Osteological Analysis}

Within archaeological practice, osteological analysis refers to the forensic examination of human remains. Examining bones and tissues, including skeletal structure, microbone morphology, disease pathology, ossification, and biophysics, is used to verify the identity of the deceased, as well as to reconstruct the circumstances of their deaths and recover the history and memory of former life. According to Weizman and Thomas Keenan, osteological analysis allows us to recover and represent "not just the moment of death but the entire history of a life- a sequence of illnesses, incidents, and accidents, along with conditions of nutrition, labor, and habit- that is fossilized into the morphology and texture of bones" (19). The authors goes on to say that "the bones of the skeleton are exposed to 
life in a similar way that photographic film is exposed to light. A life, understood as an extended set of exposures to a myriad of forces (labor, location, nutrition, violence, and so on) is projected onto a moving, growing, and contracting negative, which is the body in life" (20).

As a result, osteological analysis has become particularly important to the archaeology of genocide and other forms of cultural violence and atrocity. Through the forensic examination of victim remains, the archaeology of atrocity seeks to restore a sense of political subjectivity to victims who have been utterly desubjectified by genocidal violence. In this context, osteological analysis is particularly important within plantation archaeology. According to Samford, osteological analysis is often utilized within plantation archaeologies as a method of representing the trauma and violence of slavery. The "photographic film" of bones and tissues can indicate overt physical trauma, as well as sustained patterns of abuse: "Studies focusing on the dentition of skeletons... have shown, for example, very severe growth arrest lines (hypoplasia) indicative of extreme dietary deficiency or starvation; various types of malocclusion also reflect conditions of malnutrition" (20).

The use of osteological analysis to represent the violence and trauma of slavery is also intended to supplement the perceived instability, ambiguity, or unreliability of witness and literary testimony in the form of documentary evidence. According to Samford, "Osteological and pathological conditions not addressed in the documents have been observed on skeletal material from Newton and elsewhere" (26). As a result, "the skeletal data, in short, provides an independent data source and expansion or verification of narrative or literary sources" (26). In this way, by privileging the forensic testimony of osteological analysis over the witness testimony of documentary or narrative evidence, plantation archaeologists engage the belief that osteological analysis allows us to recover an "objective" reality and representation of slavery, to externalize its traumatic memory and meaning.

However, osteological analysis also inhabits a site of slippage and paradox. "Osteological," from the root "osteon" meaning bone, and "logia" meaning to speak, gestures at an etymological point of rupture, as does another term often used to refer to osteological analysis: "osteobiography." "To speak" and the term "biography" infer both witness and literary testimony. If osteological analysis is intended to subvert the ambiguity of the narrative and speech of the witness as subject, what does it mean to make bones "speak," to "write" and "read" them as text, as biography? In this way, osteological analysis hints at a fundamental relationship between testimonial forms: a destabilization of hierarchy at the site of etymology.

This inherent, etymological rupture between testimonial forms is further repeated within the practice of osteological analysis itself. Although osteological analysis is meant to resolve the ambiguity of witness and literary testimony, the process of supposedly recovering an "objective" re-creation and externalization of traumatic memory via material evidence inevitably requires a process of inscription, presentation, interpretation, and translation by a speaking and literary subject. In order to construct the testimony of material evidence, someone must translate the "speech" of the object and speak for it. As a result, "the predicament that characterizes the witness, for better or worse (faulty memory and ambiguity, for example) now appears as the state of the material object as well" (23). In this way, osteological analysis, by attempting to re-subjectify victim remains, also moves through witness testimony. As a result, something of the "residue" of ambiguity and impossibility that characterizes witness testimony is transferred and replicated by the material testimony of bones. In addition, by constructing a "biography" of bones, in a sense "inscribing" bones with meaning and signification, the material testimony of osteological analysis passes into and out of the realm of literary testimony, with victim remains being "written" and "read" as texts. In 
this way, while osteological analysis is intended as a means by which to externalize the traumatic memory and meaning of slavery, its meaning cannot be purely extracted from its own context of meaning-making — something of the "residue" or trace of interpretation, translation, and analysis taints its meaning via the very process of extraction. Osteological analysis, rather than interpreting the "sign" and signification of bones, instead renders bones another sign in a further deferral of meaning. Here, rather than resolve the ambiguity and impossibility of witness and literary testimony in order to externalize memory and meaning, we see that osteological analysis folds and refolds into the testimonial realms of the literary and the witness, destabilizing hierarchies of testimony. In this way, osteological analysis also embodies a "lacuna” of bearing witness.

This "lacuna," the inherent rupture and impossibility of osteological analysis, has specific implications to its practice in the plantation archeology of slavery. Osteological analysis, through the forensic analysis of victim remains to verify identity and reconstruct traumatic memory and meaning, attempts to return victims to subjectivity, to resubjectify what was stripped away by the inherent objectification, commodification, and fetishization of slavery. However, the methods and practice of the osteological analysis of slave remains constantly undercut their own project and even repeat the dynamics of violence inherent to slavery. Although osteological analysis aims to "resubjectify" victim remains via identification, in order to enact identification, all of these instruments and objects become commingled with traces of the human: something must be put into the DNA amplifier, the blood card, the centrifuge; the plastic boxes do not remain empty. Yet in the process, these traces of the individual, the subject, the missing person, are effectively annulled, flattened out into the very same equipment or instrumental level as every other item on the list, the human remains losing their remaining identity to the very tools and objects meant to identify them. (172)

Mapping this analysis specifically onto the osteological analysis of plantation archaeology, victim remains of slaves, in the process of resubjectification, mingle with the material instruments of osteological identification. Pressed between slides, passing into and out of centrifuge and microscope, victim remains slip into and out of material and witness testimony, subject and object, phasing between them, undergoing a continuous and simultaneous process of subjectification and desubjectification. As a result, the remains of slaves are again subjected to further abstraction, objectification, and commodification via the very processes intended to restore subjectivity. In this way, osteological analysis of plantation archaeology repeats the dynamics of violent erasure and desubjectification it aims to subvert. Rather than resolve the "lacuna" of witnessing via the material testimony of osteological analysis, plantation archaeology further illustrates the ways in which the testimony of slavery, its traumatic memory and meaning, cannot be purely extracted and externalized, instead existing always in retreat.

\section{Traumatic Object Archives: Analysis of Material Testimony and ETHNOHISTORIC Approaches in the Digital Archaeological ArChive of Plantation Slavery}

The Digital Archaeological Archive of Comparative Slavery, established by a team based within the Department of Archaeology of Monticello, is a complete digital archive of "artifact, context, spatial, image, and map data from excavated sites of plantation slavery" (1). The archive contains interactive, image-laden media representing archaeological sites in Chesapeake, Jamaica, Nevis, and St. Kitts, South Carolina, and Tennessee. Each archival representation of an individual plantation slavery site contains documentary evidence, a comprehensive excavation history, an outline 
of archaeological procedures, and a methods summary of research and analysis. In addition, the archive also contains image-laden object galleries highlighting artifacts, documents, and maps from each of the individual archaeological sites. As a result, the content of the Digital Archaeological Archive combines images of objects with the presence of accompanying texts.

The Digital Archaeological Archive incorporates several methods characteristic of plantation archaeology. Within plantation archaeology, and demonstrated within the Digital Archaeological Archive, the presence of material culture is used to establish and verify "slave status," an archaeological term indicating the presence of slaves at a site. In addition, material culture is used to reconstruct the experience of slave life, to excavate and externalize the memory of slavery. According to Frederick W. Lange and Jerome S. Handler, patterns in the presence of material culture can establish and verify slave status of a site and represent the experience of slave life at a site where documentary evidence is seen as ambiguous or inadequate. "Documentary sources have generally been vague on slave material culture ... Material culture is very unevenly reported in most documents" (28). As a result, material evidence supplements this perceived inadequacy. "For example, artifact remains within the identified areas have shown what the domestic kits of plantation sites consisted of ... Remains of cooking and eating dishes, food processing equipment, and faunal and floral remains have provided some hard data on what slaves ate ... a point that was ambiguous in the documentation" (27). In this way, plantation archaeology presents material evidence as a means by which to fill the "gaps" in documentary evidence in order to produce a pure externalization of the memory of slavery.

The use of material culture as evidence to supplement the instability and inadequacy of documentary evidence is further reflected within ethnohistorical archaeology approaches, which are favored within plantation archaeology and replicated within the textual and material interplay of the Digital Archaeological Archive. Within ethnohistorical approaches, an interplay of documentary and material evidence is favored in order to verify slave status and reconstruct slave life. However, the interplay of documentary and material evidence within ethnohistorical approaches also implicitly privileges material evidence within this archaeological framing. Descriptions of ethnohistorical models within the scholarship of plantation archaeology emphasize the ways in which the interplay of material and documentary evidence is utilized specifically to supplement textual inadequacy. "Historic sites of archaeology- using an ethnohistoric methodology emphasizing an interplay between the documentary and archaeological data bases- offers the potential to develop quantifiable patterns ... The delineation of patterns with a high probability of indicating plantation slavery conditions will allow us to search for these patterns in undocumented sites or, by extension, to search for evidence in preliterate sites as well” (28, emphasis mine). As a result, "There is a much higher probability than there was 10 years ago that slavery can be defined from purely archaeological data" (28). Here, the interplay between material and documentary evidence within ethnohistorical methods in plantation archaeology is revealed as a means by which to supplement the ambiguity of the textual via the introduction of the material in order to establish slave status and reconstruct the experience of slave life. In this way, both the use of material culture and ethnohistorical approaches within plantation archaeology can be understood as forms of material testimony intended to resolve the "lacuna" of literary and witness testimonies in order to externalize the traumatic memory of slavery.

However, the use of material culture and ethnohistorical methodology also embodies a site of profound rupture and slippage, as illustrated in the Digital Archaeological Archive. Within the Digital Archaeological Archive, images of excavated objects are presented alongside accompanying 
textual descriptions and documentation intended to contextualize the material culture of slavery, to capture and externalize its memory and meaning. However, this interplay of the material and textual automatically problematizes its own project and points to a constant dehierarchization and slippage between testimonial forms. Texts that accompany images of objects in the archive describe the object itself, as well as speculate on how the object would have been used in the material culture of slave life. By describing excavated objects and speculating on their use, the Digital Archaeological Archive enacts an inevitable and simultaneous process of subjectification and narrativization in which objects are translated, interpreted, and implicitly fictionalized. In order for the traumatic memory of slavery to be excavated and externialized via material testimony, objects must be made to "speak" as subjects, as well as "written" and "read" as "texts." This interplay of documentary and material evidence within the Digital Archaeological Archive reveals a fundamental slippage between testimonies; in order to extract material testimony from excavated objects, the objects of the Digital Archaeological Archive must pass into and out of witness and literary dimensions of testimony. In addition, rather than extracting a pure externalization of meaning and memory, material testimony becomes always implicated in the process of its own extraction-it can never get outside itself. Instead of extracting a pure externalization of memory from the testimony of excavated objects, the Digital Archaeological Archive reveals the objects themselves as another sign, enacting an endless deferral of meaning in which what is analyzed contains always the residue of its own interpretation. In this way, rather than resolve the ambiguity of literary and witness testimony, the Digital Archaeological Archives embody the same "lacuna" of testimony, the inherent impossibility of bearing witness.

This "lacuna" of material testimony within the Digital Archaeological Archive has specific implications to the field of plantation archaeology. The interplay of object and text within the Digital Archaeological Archive, in the very process of verifying slave status and reconstructing the memory of slavery, also participates in erasure and rhetorically replicates the dynamics of the violence of slavery itself. Within plantation archaeology and the Digital Archaeological Archive, the verification of slave status and reconstructing the lives of slaves via material testimony is supposedly intended to subvert the violence and erasure of slavery, memorializing memory and returning slaves to subjectification. However, in the process of verifying the presence of slaves at a site via material culture, the bodies and lives of slaves are represented by and reduced to objects. In this way, the extraction and exteriorization of the traumatic memory of slavery requires that the slave be made object, the process of subjectification engaging a simultaneous desubjectification. In this way, in the process of verifying slave status based on material evidence, the Digital Archaeological Archive repeats the objectification and commodification of slave bodies and lives inherent to the violence of slavery itself.

In a similar vein, while the interplay between documentary and material evidence in the Digital Archaeological Archive is intended to externalize the memory of slavery by recreating and representing the lives of slaves, slaves themselves are strangely absent from the archive. Slaves are rarely mentioned; the few mentions of slaves within the archive rhetorically repeat dynamics of violence and erasure. Only three slaves are mentioned and given biographies in the archive. The biographies of the slaves Little George, Isaac Jefferson, and Joe Fossett can be found in the documentary evidence section of an archaeological site at Monticello called Building D/j, which functioned as a blacksmith's and nailer's shop. The biographies are presented alongside images of excavated objects from the site, as well as maps and images of the excavated site itself. The biography of Little George, a mere four sentences, includes that George “... ran Monticello's blacksmith 
shop from 1783 to his death in 1799 ... George was selected to be the first manager of Jefferson's nail-making business in 1794 and even received a small portion of its profits" (1). Similarly, the five-sentence biography of Isaac Jefferson includes that he "studied tinsmithing during an apprenticeship in Philadelphia" and "became one of the most productive nail-makers in Jefferson's nail-manufacturing shop" (1). Finally, the 4 sentence biography of Joe Fossett emphasizes that "[a]s a blacksmith, Joe was allowed to keep one-sixth of the blacksmith's shop's profits" and that "Joe was one of five slaves freed in Jefferson's will" (1). The selective inclusion and framing of slave biography subtly erases and romanticizes slave labor and is invested in reproducing the a historical idea of the "benevolent/kind master" in Thomas Jefferson. Rather than excavate and represent the cultural memory and experience of slavery, the ethnohistorical use of biography in the Digital Archaeological Archive rhetorically commodifies the lives and bodies of slaves in service of a perpetual, coerced production of white guilt and benevolent fantasy. Slaves are objectified and erased in biography, forced to perform a continuing ideological labor even in death. In this way, the ethnohistorical use of biography in the Digital Archaeological Archive rhetorically repeats the violence of slavery. The material testimony and ethnohistorical methods of the Digital Archaeological Archive, rather than externalize the traumatic memory of slavery and interpret its meaning, instead constantly undercuts its own project. The Digital Archaeological Archive illustrate again that plantation archaeology cannot speak outside of itself. The process of extracting the memory of slavery is always tainted by the very process of its extraction, endlessly deferring meaning and representation. Rather than resolve the "lacuna" of witnessing, plantation archaeology exists always within its impossibility.

\section{Concluding Summary, Paths of Intervention, and Collective Healing}

This analysis enacted multiple analytic processes to examine plantation archaeology as a form of testimony and bearing witness to the atrocity of slavery. By applying literary analysis to material testimony of slavery, and by exploring representation of material testimonies in the literature of slavery, this paper aims to open up the relationship between literary and material testimonies of slavery and allow them to "speak" to one another. Analyzing the representation of Florens's "telling” in Toni Morrison's A Mercy reveals a fundamental slippage and dehierchization of witness, literary, and material forms of testimony that allows us to think toward the ways in which plantation archaeology also embodies a "lacuna" of bearing witness. The rhetoric of osteological analysis and the Digital Archaeological Archive of Comparative Slavery reveals that the methods and practice of plantation archaeology, rather than resolve the "lacuna" of testimony by recovering an "objective" memory of slavery, instead embodies a site of paradox and traumatic rupture. Applying Felman's concept of the "irreducibility" of literature to plantation archaeology reveals that its material testimony cannot be purely extracted and exteriorized but is always tainted by the very methods of its analysis. In addition, this critical examination reveals that the archaeology of plantation slavery often rhetorically repeats the violence of slavery itself.

I wish to gesture at potential paths to address these sites of rupture within plantation archaeology and pursue both intervention and collective healing. Here, we return again to Agamben's theory of the "lacuna" in which he says that this inherent crisis of testimony is not to be resolved in order to achieve representation. The location of testimony cannot be found by resolving its "lacuna"; rather, testimony can be understood as its inherent "lacuna" itself. Similarly, in her concept of the "irreducibility" of literature, Felman argues that this irreducibility is in fact the essence of literary testimony, embodying what she calls "the literary thing." Any method of investigation and 
commemoration of the cultural trauma and violence of slavery will therefore be called to acknowledge the inherent inability of testimony to "say itself," to be extracted without being tainted by its very methods of externalization.

Weizman puts forth his concept of "Forensis" as means of intervening in the rhetorical violence and erasure of forensic archaeological practice. The term "Forensis" refers to a critical process in which the methods of archaeological analysis are subjected to simultaneous critique; "Forensis" therefore combines forensic methods of research and investigation, as well as simultaneous critical analysis of these practices, in order to interrogate their epistemologies, assumptions, protocols, and politics of knowledge production" (4). In this way, Forensis opens potential for harnessing forensic practice as a method of intervention via a turning of the forensic gaze.

In Testimony: The Crises of Witnessing in Literature, Psychoanalysis, and History, Felman and Laub engage with the importance of examining the relationship between literature and testimony to understand the position of bearing witness within history and contemporary life. In addition, Felman argues that acknowledging and "claiming" the "irreducibility" of literature, the impossibility of testimony, enacts a form of "radical loss." Enacting a claiming and recognition of this "loss" of meaning, according to Felman, "is the only way one has of winning it" (127). By presenting a "Forensis" and literary critique of the methods of plantation archaeology, this paper is intended to model the very paradigms of critical intervention and healing it pursues. In addition, the author of this paper wishes to recognize that, in an attempt to externalize the meaning of the testimony of plantation archaeology, this paper is further implicated in the deferral of meaning it attempts to orient and fix. By claiming the irreducibility of our own analysis, this paper also attempts to enact a form of "radical loss."

To end our analysis, we again return to Florens's testimony in A Mercy. Upon carving her "telling" into the walls, rendering it as image and object, Florens realizes her testimony cannot be extracted. "These careful words, closed up and wide open, will talk only to themselves" (188). Here, Morrison pushes us to realize that the unexcavateable testimony of slavery, including its material testimonies, cannot be said outside its own methods of saying. 


\section{WOrks Cited}

Agamben, Georgio. Remnants of Auschwitz: The Witness and the Archive. New York:

Zone, 2002. Print.

n.p. Digital Archeological Archive of Comparative Slavery. Department of Archaeology at Monticello, n.d. Web. 9 Sept. 2014.

Felman, Shoshanna, and Dori Laub. Testimony: Crises of Witnessing Literature, Psychoanalysis, and History. New York: Routledge, 1992. Print.

Felman, Shoshanna. Writing and Madness: Literature/Philosophy/Psychoanalysis. Palo Alto: Stanford University Press, 2003. Print.

Keenan, Thomas, and Eyal Weizman. Mengele's Skull: The Advent of Forensic Aesthetics. London: Sternberg Press, 2012.9-84. Print.

Lange, Frederick W., and Jerome S. Handler. “The Ethnohistorical Approach to Slavery." The Archaeology of Slavery and Plantation Life. Ed. Theresa A. Singleton. New York: Academic Press, 1985. Print.

Morrison, Toni. A Mercy. New York: Vintage International, 2008. Print.

Saltzman, Lisa, and Eric Rosenberg, eds. Trauma and Visuality in Modernity. New Hampshire: Dartmouth College Press, 2006. Print.

Samford, Patricia. Subfloor Pits and the Archaeology of Slavery in Colonial Virginia. Tuscaloosa: University of Alabama Press, 2007. Print.

Sheikh, Shela. "Forensic Theater: Grupa Spomenik's Pythagorean Lecture: Mathemes of Re-Association.” Forensis: The Architecture of Public Truth. Ed. Eyal Weizman. London: Stenberg UP, 2014. 166-186. Print.

Weizman, Eyal. Introduction. Forensis: The Architecture of Public Truth. By Weizman. London: Stenberg UP, 2014. Print. 